\title{
PORT STATE CONTROL AS AN IDEAL SYSTEM
}

\author{
POPESCU, C[orina]; VARSAMI, A[nastasia] E[lena]; HANZU - PAZARA, R[adu] \& ACOMI, N[icoleta]
}

\begin{abstract}
It is well known along the history, that ship-owners inspected their ships to see if these were apt for navigation. The main concern throughout the centuries was the ship floatability. This paper discusses the safety measures and other issues about the crew's welfare and life which were not taken into account. Many examples from historical sources point to the fact that even kings, queens, tsars, pharaohs, sheiks and other monarchs were interested to inspect the fleet they had in command and to be certain that their ships were in good condition. In this article we are going to present how port state control represents a real step stone to the improvement of the maritime safety, shipbuilding and security of the marine environment.

Key words: port, maritime safety, marine environment
\end{abstract}

\section{INTRODUCTION}

Nowadays ships are more secure, the crews are more trained than their predecessors, but in spite of all these measures, accidents still happened. The evolution of modern economy and the increased concern for the marine environment, and life itself, allowed the international maritime organizations to elaborate codes, rules and regulations limiting the possibility of accidents but the same economy, has its ups and downs and the ship maintenance, or crew training can be a real challenge. Even under the hard economical times life must prevail and as it is well-known, the sea may take a big toll for carelessness.

The international maritime organizations have their own legal agencies for inspection and law implementation, to prevent the accidents at sea and loss of human lives.

Port State Control is the control of foreign flagged ships in national ports. Since the control systems used by the other partners in the shipping world have proven ineffective in eradicating all substandard vessels from the seas, port state control stays in practice. However, port state control is not, and can never be a substitute for the proper exercise of flag state responsibility. The primary responsibility to safeguard against substandard ships lies with the flag states. It is when flag states fail to meet their commitments that the port state comes into play.

When one reads the literature about the port state control, one comes across statements to the effect that "port state control is the last safety net and in an ideal world the port state control would not be necessary" (Oya Ozcayir, 2004).

\section{PORT STATE CONTROL AS AN IDEAL SYSTEM}

International conventions have been created and developed on the basis of the safety of the ships being regulated by the flag states. The International Maritime Organization (IMO), a specialized agency of the United Nations, started to develop international treaties and other legislation concerning safety and marine pollution prevention in the 1950s in order to develop international standards which would replace the multiplicity of national legislation which then existed. IMO has produced a mass of legislation over the years and majority of countries are members of these conventions. If the majority of the countries are members of these conventions, why is it still possible to find ship owners or manning agents who force seafarers to risk their health and lives at sea, or find ships which are unsafe and do not comply with the required technical conditions under the international conventions? Or why are there so many crew members who do not know what to do in case of an emergency?

Shipping is not failing in ratifying new conventions and international community is not failing in adopting necessary legislation; but shipping is failing in the application and enforcement of international legislation, especially the ones on safety, pollution and crew welfare. As a general rule the implementation of international conventions is the responsibility of the states that ratified them. Governments ratifying the international instruments are obliged to incorporate the provisions into their national legislation. However, in practice enforcement of international conventions raises many problems. They may take a long time to be incorporated into the national legal system of each state. The coming into force of a convention does not necessarily mean its effective enforcement.

For a considerable period of time, the shipping community relied on the flag states to provide overall control. This has been very difficult to achieve especially with the advent of flags of convenience. Flag states also have gradually relied upon more and more on classification societies to regulate and control the standards laid down by the IMO. However, the control mechanisms applied by the flag state and classification societies have proven to be not good enough to remove the allsubstandard vessels from the industry.

\section{THE RULES THAT GOVERN PORT STATE CONTROL ACTIVITIES}

In November 1995, IMO adopted resolution A.787 (19)Procedures for Port State Control. The resolution was amended in 1999 by resolution A.882 (21) and will no doubt be further amended in the future. The resolution is intended to provide basic guidance on the conduct of port state control procedures and afford consistency in the conduct of such inspections, the recognition of deficiencies of a ship, its equipment, its crew and the application of control procedures. It is published by IMO as a booklet with the title of "Procedures for Port State Control".

The procedures are not mandatory and only offer guidance to port states.

The intention of port state control is not to enforce on foreign merchant shipping any requirement which goes beyond convention requirements. In other words, the MOUs do not extend the scope of port state control beyond the international convention requirements: 
- The prime responsibility for compliance with the requirements laid down in the international maritime conventions lies with the shipowner/operator. The responsibility for ensuring such compliance remains with the flag state.

- $\quad$ Each maritime authority gives effect to the provisions of the relevant MOUs.

- "Each authority has to ensure that foreign merchant ships visiting its ports comply with the standards laid down in the relevant conventions and all amendments thereto in force" (Gibson, 2006). In this context, a participating maritime authority regards a ship flying the flag of another member state as a foreign ship too.

- The MOUs provide for a total number of inspections, expressed in terms of a percentage, that each of the states party to the relevant MOU shall conduct. Under the Paris MOU the member states have agreed to inspect $25 \%$ of the estimated number of individual foreign merchant ships which enter their ports during a 12 month period. This percentage is different in other MOUs. The Tokyo MOU refers to a $75 \%$ value and the Indian Ocean MOU refers to $10 \%$ value while Viña del Mar, Caribbean, Mediterranean, West and Central African and the Black Sea MOUs mention a minimum of $15 \%$ annual inspections.

- IMO and ILO conventions provide the basis for inspections under the MOUs.

- All possible efforts are made to avoid unduly detaining or delaying a ship.

- In principle, there will be no discrimination as to flag.

- Inspections are generally unannounced.

- In general ships will not be inspected within six months of a previous inspection in a MOU port, unless there are "clear grounds" for inspection.

Under the MOUs, the "clear grounds" justifying the undertaking of further inspections are defined as:

- a report or notification by another authority;

- a report or complaint by the master, a crew member, or any person or organization with a legitimate interest in the safe operation of the ship, the shipboard living and working conditions, or the prevention of pollution, unless the authority deems the report or complaint to be manifestly unfounded; and

- $\quad$ other indications which may warrant a more detailed or an expanded inspection.

In addition to this list, there is a second series of specific "clear grounds" concerning the compliance of vessels with onboard operational requirements. These are:

- $\quad$ evidence of operational shortcomings revealed during port state control procedures in accordance with the 1974 SOLAS Convention, MARPOL 73/78, and the 1978 STCW Convention;

- evidence of cargo and other operations not being conducted safely or in accordance with IMO guidelines;

- involvement of the ship in incidents due to failure to comply with operational requirements;

- $\quad$ evidence, from the witnessing of a fire or abandoned ship drill, that the crew are not familiar with essential procedures;

- absence of up-to-date muster list; and

- indications that the relevant crew members are unable to communicate appropriately with each other, or with other persons on board, or that the ship is unable to communicate with the shoe-based authorities either in a common language or in the language of those authorities.

\section{DEVELOPMENT OF MODERN PORT STATE CONTROL}

"Port State Control is an increasingly important measure for the elimination of sub-standard ships and if a vessel is found to have deficiencies or is detained as a result of failing a port state inspection, then high commercial penalties may be incurred" (Thoresen, 2006). Masters and officers understand how Port State Control works, and also the importance of maintaining vessels in accordance with International Conventions. While Flag administrations and Classification Societies have an important role to play in supervising the safe operation and examining the structural condition of ships, it is the responsibility of the Master and crew to ensure on a daily basis that they are following all the relevant Codes and Conventions.

The new directives of January 1, 2011 impose upon the reinforcement of the port state control efficiency. The primary responsibility for control remains with the individual flag state. However, the demand for increased control and enforcement makes it necessary to redefine the traditional role and enforcement methods port state control authorities. The effectiveness of the measures will be highly dependent on whether uniform practices can be achieved. As the right to refuse access may be based on inspections undertaken in other member states, uniform practices are of obvious importance. One risk is that ports of convenience may develop, which have less stringent enforcement. The directive may therefore give rise to competition law problems that must be monitored closely.

\section{CONCLUSION}

The Port State Control is one of the most important port authority in all Memoranda countries and in the USA. The main activity of Port State Control is to insure the maritime safety and to eliminate the sub-standard ships from the sea. The detentions and other methods of restrictions regarding the substandard ships are some legal ways to obtain a more secure and clear sea. The main concern of the nowadays international maritime organizations is to preserve the marine environment and life at sea. Safe and security must be the main concern not only for ship-owners, masters and crews but for the port authorities also. The development of the international maritime laws and the increased research in shipbuilding are subjects for a well-prepared PSCO. The recommended training schemes in the present work meet all the requirements for a well trained PSCO. However, the training schemes are infinite, according to the development of the modern navigation and maritime safety.

\section{REFERENCES}

Gibson, S. (2006). Ports \& Terminals Guide 2007-2008 Volume 1, Fairplay Publications Inc, ISBN 10190129088 3, London

Oya Ozcayir, Z. (2004). Port State Control, $2^{\text {nd }}$ Edition, Publisher Lloyd's List, ISBN 978-1-84311-328-7, London

Thoresen, C.A. (2006). Port Designer's Handbook: Recommendations and Guidelines, MPG Books, ISBN 0 72773228 5, Cornwall

International Convention for the Safety of Life at Sea, 1974 (1997). Consolidated Text of the Annex to the 1974 SOLAS convention and the 1978 Protocol Relating Thereto Incorporating the Amendments adopted up to 1995

Marine Environment Protection Committee 50, (1993). IMO, London

MARPOL 73/78 Convention- Consolidated Edition, (2002). IMO, London

Standards of Training, Certification and Watchkeeping, (1996) IMO, London 